\title{
Optimism of characters in Andrea Hirata's Novel Entitled "Orang-Orang Biasa": An Overview of Literature Psychology
}

\author{
Petrus Afendi $\mathbf{1}^{*}$ \\ ${ }^{1}$ Magister Pendidikan Bahasa Indonesia, Universitas Muhammadiyah Malang, Indonesia \\ *Email: petrusafendi@gmail.com
}

\begin{abstract}
Optimisme adalah suatu sikap atau pola berpikir yang positif terhadap suatu persoalan atau permasalahan dengan pertahanan diri yang kuat sehingga tumbuh rasa percaya diri. Pola pikir optimisme ini cenderung kurang dimiliki oleh seseorang karena beberapa alasan salah satunya sumber daya manusia yang kurang membuat seseorang tidak percaya diri dalam mengambil suatu keputusan. Penelitian ini bertujuan untuk mendeskripsikan aspek dan fungsi optimisme tokoh dalam novel Orang-Orang Biasa Karya Andrea Hirata. Pendekatan yang digunakan dalam menganalisis ini dengan meggunakan teori psikologi sastra dengan menggunakan teori psikologi yang difokuskan pada aspek optimisme yang dikemukakan oleh Goleman. Jenis penelitian yang digunakan adalah penelitian kualitatif dengan sumber data adalah novel Orang-Orang Biasa Karya Andrea Hirata. Metode pengumpulan data menggunakan studi dokumentasi yakni dengan cara membaca secara ekstensif dan berulangulang untuk mendapatkan isi sesuai dengan kajian yang diinginkan. Teknik analisis dengan cara mereduksi data atau memilih data, penyajian data berupa kutipan, dan penarikan kesimpulan sebagai tahap akhir dari penelitian. Berdasarkan hasil penelitian menunjukan bahwa aspek optimisme dalam novel Orang-Orang Biasa karya Andrea Hirata ditunjukan dalam berbagai nilai yaitu (1) memiliki harapan yang tinggi, (2) tidak mudah putus asa, (3) mampu memotivasi diri, kepercayaan diri yang tinggi dan (4) tidak bersikap pasrah sedangkan fungsi dari optimisme dalam novel adalah (1) sebagai sarana motivasi untuk memperkuat diri, (2) sebagai bagian dari bentuk pertahanan diri untuk mengatasi persoalan hidup dan (3) optimisme sebagai sistem pendukung.
\end{abstract}

Kata Kunci: Optimisme, Novel, Psikologi Sastra

\begin{abstract}
Optimism is an attitude or pattern of positive thinking towards a problem or problem with strong self-defense so that self-confidence grows. This optimistic mindset tends to be less owned by someone for several reasons: lack of human resources, which makes a person not confident in making a decision. This study describes the aspects and functions of the character's optimism in Andrea Hirata's Orang-Orang Biasa novel. The approach used in this analysis uses literature psychology theory, which focuses on the optimism aspect proposed by Goleman. The type of research used is qualitative research with the data source is the novel Orang-Ordinary by Andrea Hirata. The data collection method used a documentation study, namely by reading extensively and repeatedly to get the content by the desired study. The analysis technique is by reducing the data or selecting the data, presenting the data in quotations, and drawing conclusions as the final stage of the research. Based on the results of the study, it shows that the optimism aspect in Andrea Hirata's Orang-Orang Biasa novel is shown in various values, namely (1) having high expectations, (2) not being easily discouraged, (3) being able to motivate oneself, high self-confidence and (4) not being resigned while the function of optimism in the novel is (1) as a means of motivation to strengthen oneself, (2) as part of a form of self-defense to overcome life's problems and (3) optimism as a support system.
\end{abstract}

Keywords: Optimism, Novel, Literature Work

\footnotetext{
${ }^{*}$ Corresponding author.

Received February 04, 2021; Accepted July 04, 2021; Available online October 25, 2021

This is an open access article under the CC BY-SA license. Copyright $@ 2021$ by Author. Published by Universitas Pendidikan Ganesha.
} 


\section{INTRODUCTION}

Literature is one of the reflections in the life of an author. Authors can develop their ideas, thoughts, and opinions or other people's experiences who inspire their writing. In developing ideas, literature can be an inspiration for others. One form of literature that has much inspiration is the novel. The author is interested in researching the novel Orang-Orang Biasa by Adrea Hirata is the storyline and the characteristics of the characters. The very interesting thing about the storyline is that the characters are from a less educated background, but they can do big things. The character's optimistic aspect is very inspiring. It is important to study because now many people feel pessimistic about their lives. People tend to feel hopeless. The main cause is the low level of education which affects human resources. This novel presents a different view of the characters. Even though their education level is low and they did not finish elementary school, they have big dreams to achieve their goals. It makes the writer interested in studying further the contents of this novel. Literature is an important part present more imaginative elements. The moral message contained in it is something to be reckoned with (Darma Putra \& Laksmita Sari, 2019; Sulistyo, 2018; Utomo et al., 2020).

Literature research is an important activity for the development of literature. The literature will develop because of the sharp concepts, theories, and methodologies. Literature research is very necessary because literature is growing rapidly in the development of science. In connection with this research, the author reviews literature psychology because this novel displays more values and functions of the character's optimism in dealing with problems. Literature psychology is important because there are several advantages: first, to examine more in terms of character aspects; second, the literature psychology approach provides feedback to researchers on character issues; third, psychological research is very helpful to analyze literature related to psychological problems (NurDayana \& Andalas, 2019)(Masnuatul, 2014).

The author focuses on novels studied entitled Orang-Orang Biasa by Andrea Hirata. The writer must explore the aspects of the novel in detail. The novel is built by intrinsic and extrinsic elements as one of the genres of literature. A novel is a work of fiction that contains an idealized and imaginative life model. Novels are built by intrinsic elements such as events, plots, characters and characterizations, setting, point of view. At the same time, the external elements include moral aspects, social aspects, cultural aspects. The optimism aspect and function are very strong if related to the focus of the problems discussed in the novel. This novel displays the dominant character, traits, and behavior to build optimism. The characters depicted in this novel have high confidence and optimism in responding to the problems they experience despite all the limitations. Human resources and a low level of education are not obstacles to reaching their goals. The characters have high expectations and self-confidence to arouse their sense of optimism.

Several studies are relevant to this research. Research states that Sabari's positive traits as the main character in the novel "Ayah" are patience, social care, peace, compassion, and never giving up. (Bura, 2019). The function of the positive character possessed by the main character Sabari is that attitude functions as a behavioral regulator, Sabari's extraordinary patience is also seen when he patiently accepts Bogel Leboi's unpleasant treatment towards him. Then the research states that the form of analysis of moral values is found in the novel "Ibu, Sedang Apa?" Edi AH lyubenu's work is the human relationship with oneself, the human relationship with others, the human relationship with God, the human relationship with nature (Layali et al., 2021).

This research has a novelty compared to previous studies because it has not been studied before. Although the novel "Orang-orang Biasa" by Andrea Hirata has been widely studied. The aspects of the study are more on moral values, analysis of the value of character education, aspects of crime, aspects of diction, style of language, while the aspect of optimism has not been studied previously. Thus, this novel was chosen as a study material in terms of the form and function of optimism.

\section{METHOD}

The type of research used to analyze the novel "Orang-Orang Biasa" by Andrea Hirata is qualitative research with a literature psychology approach. This type of qualitative research is suitable for the analysis of this novel because the author identifies and describes the views of the characters, dialogues between characters, story narratives, and the use of sentences in Andrea Hirata's novel "Orang-Orang Biasa." Qualitative research in the form of data in the form of sentences or narratives from research subjects or respondents obtained through a data 
collection technique and then analyzed to produce findings that will answer the research questions posed. The data source used in this research is the novel "Orang-Orang Biasa" by Andrea Hirata. According to the problem formulation, the data used are a dialogue between characters and narrative.

The data collection technique used a documentation study, namely by reading extensively and repeatedly to get the content by the desired study. In the novel "Orang-Orang Biasa" by Andrea Hirata, there are many characters with different characteristics, so the author must examine them carefully and in detail to obtain information according to the study conducted. The author also records the parts that are considered important so that no part is missed. Besides that, the psychological aspect of the character is also a consideration for the author in conducting this study.

The data analysis technique used is content analysis. Descriptive analysis is a content analysis intended to describe a message or a particular text in detail. The qualitative descriptive technique is done to get a picture related to the aspect of optimism owned by the character. The author must trace and examine each character to get a detailed picture related to the optimistic aspect of the character. Qualitative content analysis techniques are used by reducing data or selecting data, presenting data in the form of quotes, and drawing conclusions as the final stage of the research.

\section{RESULT AND DISCUSSION}

Based on the data obtained, the writer finds the aspects and functions of optimism in Andrea Hirata's novel "Orang-Orang Biasa" as follows:

\section{Aspects of Optimism in the Novel Orang-Orang Biasa by Andrea Hirata Has High Expectations}

A human being should have hope, which hopefully makes us have a purpose in life so that our lives become more directed and have a clear path of life. How did the character Inspector Abdul Rojali have high expectations as expressed, "My brother is crying, isn't he? Oh, brother, don't cry, go home, study again, take another test at the nursing school next year, you will graduate next year. The teacher took over the cellphone again. If you can enter a private nursing school, you can find a scholarship later, sir. Sorry ma'am, I'm still actively working, many poor children need the scholarship more." (Andrea Hirata, 2019: 65).

The quote makes it very clear that Inspector Abdul Rojali has great hope. He continues to motivate his son not to give up. When associated with reality, sometimes humans are quick to despair and don't want to try if they experience a failure in any form. So that we can reflect on this character's experience to continue to have the fighting power and hope to achieve the future and the goals we dream of.

\section{Not easily discouraged}

Not easily discouraged is an attitude that every believer must own. Keep the spirit even though the terrain is very difficult. Because despair only makes us shackled by the problems we face. Can't think to solve problems. How does Tohirin's character have an attitude that doesn't give up easily, as expressed in this sentence, "I won't take a step back, watch them this time! Can't wait Tohirin rub Basstardin and Boron. "Fight or be resisted!" When speaking, Handai really likes to use pearls of wisdom. This fight is our time to fight! Greet Rusip while raising his fist. They put their hands together again like a volleyball team had done a thunderbolt, then screamed incoherently while throwing their hands away." (Andrea Hirata, 2019: 18).

The footage shows that the character Tohirin has the courage and is not easily discouraged in the face of bullying and violence but can respond to these problems with resistance. If it is associated with reality, sometimes people feel hopeless if they experience a tense situation or serious problem. The problem does not have to be faced with violence or resistance as experienced by the characters but can be resolved properly.

\section{Able to Motivate Yourself}

Self-motivation is an attitude shown to oneself to achieve the desired goals. This attitude is in the form of a person's words and actions. Motivating ourselves is the same as being patient through a trial that is befalling us and accepting it gracefully. How can Aini's character motivate herself as expressed in this sentence "Why are you studying so hard, Aini? I have been a teacher for 35 years, I have never seen a student as persistent as you. Because 
now I have ideals, ma'am. Oh, so you didn't have a dream? No, ma'am. Tell me Aini, What is your goal now? Aini raised her face. She looked at Mrs. Desi, she remembered her father, reminisced about her tears. I want to be a doctor, ma'am. Oh, that's great! What doctor? Expert doctor, ma'am. What kind of doctor? I don't know, Mom, I just want to be an expert doctor." (Andrea Hirata, 2019: 45).

Aini's character has strong self-motivation and noble ideals to become an expert doctor in the quote. Even in economic limitations, Aini's character seems persistent in her struggle to achieve her dream. Suppose it is associated with the reality that self-motivation to fight is low. In that case, most teenagers do not have a strong intention or effort, let alone struggle because of economic limitations. It motivates us to continue to have high motivation so that all our hopes and ideals can be realized

\section{High Confidence}

Confidence is something that must exist in humans. A confident person tends to believe in his abilities. Don't depend on others. Want to try as much as possible to achieve what you want. How Nihe's character has a high self-confidence, as expressed in this sentence "Even though we don't know how to rob a bank, our spirits are still high! Success or fail is a matter of later! The important thing is enthusiasm! We will not be easily defeated as long as we have nails, hands, feet, and cell phones! I'm excited! I'm not worried! I am happy!" (Andrea Hirata,2019:116).

The quote describes the character of Nihe, who has high and strong self-confidence. However, the actions taken by the character fall into the category of criminality and are dangerous. The key to the character is the spirit so that his plans run smoothly and without obstacles. If we relate it to reality, robbing a bank is dangerous and falls into criminality. But in the context of the character's spirit to achieve their goals, we should give a thumbs up. Not because of robbing but the enthusiasm and high self-confidence to do something that should be used as an example.

\section{Never give up}

Not being resigned is the same as trying to change a situation or disaster. We are not just silent but can change it. How does Aini's character have an attitude of not giving up easily, as expressed in this sentence "You work until the president changes 15 times the salary of a coffee shop waiter, it's not enough to study medicine! Yes I know. So you still want to work as a waitress at this coffee shop! Why? So that I can save up for medical school!" (Hirata, 2019: 105106).

Aini's character does not give up easily, but she still has a high commitment and fighting spirit to reach her dream to study medicine. Economic limitations do not prevent Aini from being able to realize her dreams. In reality, we sometimes doubt and do not want to fight. People usually give up without thinking of the best way out to get out of their slump. Moreover, economic life is an important factor. We must learn from the figure of Aini, although limited in terms of economy but has the fighting power, determination, and dreams.

\section{The Function of Optimism in the Novel of Orang-Orang Biasa by Andrea Hirata: Optimism as a Motivation to Strengthen Yourself}

In this study, the optimism aspect was found to function as motivation to strengthen oneself. When viewed from the character and behavior of the ten figures starting from the figures of Nihe, Jumila, Rusip, Dinah, Debut Awaludin, Sobri, Handai, Honorun, Salud and Tohirin, they have a high sense of optimism. A sense of optimism can raise their confidence to develop. They have a high intrinsic motivation to do things in various ways and strategies. It is related to the context in everyday life. In that case, everyone must have a sense of optimism to generate intrinsic motivation in themselves and a fortress to strengthen themselves. If someone has a pessimistic feeling, the motivation to strengthen themselves will be weak, resulting in weak self-restraint, not confidence, anxiety, and afraid of failure.

\section{Optimism as a form of self-defense to overcome life's problems}

Optimism also functions as a form of self-defense to overcome life's problems. The characteristics of the characters described in Andrea Hirata's novel Orang-Orang Biasa can be seen in the characters Debut Awalun, Tohirin, Rusip and Handai. They have confidence in themselves that they can overcome the problems at hand. If it is related to the context, everyone needs to have the confidence to face and overcome problems. So many problems 
occur in the surrounding environment. People tend to be unable to overcome their problems because they feel insecure, afraid to fail, give up on circumstances, and are pessimistic. It requires an attitude of optimism to have strong self-defense and overcome life's problems in the reality of their respective lives.

\section{Optimism as a support system}

Optimism also serves as a support system. If a person is reminded of success, he thinks he will succeed, has the will to succeed, has the attitude needed to succeed, and does to achieve success. In the novel, it is found that optimism which functions as a support system, is seen in all characters. They have the same determination and mission to achieve success. In reality, all these people are to succeed, but they are not supported by the intentions, attitudes, and actions to achieve the desired success. Because optimism as a support system relates to thoughts, intentions, and actions, all these things must be in line to realize the ideals and goals.

A novel is a form of storytelling about human life that is fragmentary. The disclosure technique is solid, and the elements are an integrated structure. The novel tells the extraordinary events of the lives of the characters. A good story will only describe certain details so that it is not boring and reduces the calmness of the story (Hawa, 2020; Munaris, 2011; Sumiyadi, 2016). A novel consists of the constituent elements, namely intrinsic and extrinsic elements. Intrinsic elements include themes, characterizations, plot, setting, point of view, style and atmosphere. Extrinsic elements include economics, politics, philosophy and psychology (Sa'adah, 2017; Taryanti \& Bahtiar, 2015). The role of psychology in literature is used to animate the characters consciously created by the author. From a psychological point of view, there is a connection between characterization and psychology. The characters in novels are usually shown in full, for example, those relating to behavior, traits, and habits. The soul of the characters in the novel depicts humans who live in real life as models in an author's creation. Characters play an important role in the storyline with the presence of a character, an event arises. The author uses the character to convey meaning through speech, behavior, or behavior. From this description, it can be said that the psychological element is very influential on the characterization elements in literature. The psychological dimensions are mentality, norms, morals used, temperament, feelings, attitudes and character, intelligence, special skills and abilities.

The essence of literature is fiction or what is called imagination. Imagination in literatue works is imagination based on reality (Buana, 2017; Nurhabibah \& Widiawati, 2021; Pamuji \& Fathonah, 2021). In addition to a review of optimism, the author also raises the function of optimism, motivation to strengthen oneself. In the novel, every character has passion and enthusiasm to motivate themselves to be better, not only for the characters themselves but also for their children. They also provide mutual reinforcement. Second, as part of a form of selfdefense to overcome life's problems. In the novel, all the characters have unique ways to make their goals come true, even the way they go is categorized as criminality, but they have strengths, ways, and strategies to overcome the problems they face. They have no anxiety and fear. Third, optimism also functions as a support system. It is described that all the characters have a strong determination and will so that their goals can be realized and succeeded. Optimism functions in 3 parts: positive energy, resistance, and support system.

\section{CONCLUSION}

The study of optimism in this novel covers aspects and functions. The optimism aspect has indicators, namely having high hopes, not giving up easily, motivating oneself, having high self-confidence, and not being resigned. At the same time, the function of optimism includes three things. First, optimism is a means of motivation to strengthen oneself. Second, optimism is part of a form of self-defense to overcome life's problems. The third is optimism as a support system. From the data presented, it is clear that the aspects and functions of optimism from this character need to be used as examples and applied in everyday life. The value and function of optimism can provide inspiration and motivation beneficial for oneself, others, and the environment.

\section{REFERENCES}

Buana, C. (2017). Nilai-Nilai Moralitas dalam Syair Jahiliyah Karya Zuhair Ibnu Abi Sulma. Buletin Al-Turas, 23(1). https://doi.org/10.15408/al-turas.v23i1.4803. 
Bura, T. (2019). Analisis Sifat Positif Tokoh Utama Dalam Novel Ayah. Jurnal Pesona, 5(1). https://doi.org/10.52657/jp.v5i1.1198.

Darma Putra, I. N., \& Laksmita Sari, I. A. (2019). Mendulang Mutiara Kata: Identifikasi dan Intertektualitas Ekspresi Kearifan Lokal Dalam Sastra Bali Modern. Mudra Jurnal Seni Budaya, 34(2), 2399-249. https://doi.org/10.31091/mudra.v34i2.706.

Hawa, M. (2020). Analisis Tokoh Dan Aspek Spiritual Quotient Novel Hati Suhita Karya Khilma Anis. Jurnal Educatio FKIP UNMA, 6(2), 629-634. https://doi.org/10.31949/educatio.v6i2.592.

Layali, A., Darmuki, A., \& Setiyono, J. (2021). Analisis Nilai Moral dalam Novel Ibu , Sedang Apa? Karya Edi AH lyubenu dan Hubungannya dengan Pembelajaran di SMA. Jurnal Educatio, 7(3), 705-712. https://doi.org/10.31949/educatio.v7i3.1204.

Masnuatul, H. (2014). Novel Sepatu Dahlan Karya Khrisna Pabichara; Analisis Psikologi Sastra dan Nilai Pendidikan. Jurnal Edutama FKIP PGRI Bojonegoro, 1(2), 14-24. http://dx.doi.org/10.30734/jpe.v1i2.8.

Munaris, M. (2011). Resepsi pembaca terhadap unsur fakta cerita dalam novel. Litera, 10(2), 171-182. https://doi.org/10.21831/ltr.v10i2.1161.

NurDayana, I., \& Andalas, E. F. (2019). Konflik Batin Tokoh Pak Fauzan Dan Pak Iskandar Dalam Novel :Kambing Dan Hujan" (Telaah Psikologi Sastra). FON : Jurnal Pendidikan Bahasa Dan Sastra Indonesia, 15(2), 1-11. https://doi.org/10.25134/fjpbsi.v15i2.2159.

Nurhabibah, P., \& Widiawati, H. (2021). Eksplorasi Nilai Pendidikan Karakter Dalam PetatahPetitih Sunan Gunung Jati. Fon: Jurnal Pendidikan Bahasa Dan Sastra Indonesia, 17(1), 52-64. https://doi.org/10.25134/fon.v17i1.4195.

Pamuji, S. S., \& Fathonah, S. (2021). Fantasi Modern Pada Novel Anak Queen Aura Untuk. Basindo: Jurnal Kajian Bahasa, Sastra Indonesia, Dan Pembelajarannya, 5(1), 65-77. http://journal2.um.ac.id/index.php/basindo/article/view/9783.

Sa'adah, J. (2017). Metode Pembelajaran "Picture And Picture" Dalam Menulis Teks Cerita Fiksi Novel Pada Buku Teks Bahasa Indonesia Ekspresi Diri Dan Akademik SMA/ MA/ SMK/ MAK Kelas X11 Semester 2 Kurikulum 2013. Bahastra, 37(1). https://doi.org/10.26555/bahastra.v37i1.5958.

Sulistyo, H. (2018). Representasi Konflik Politik 1965 dalam Cerpen Susuk Kekebalan karya Han Gagas. Jurnal POETIKA, 6(1), 16. https://doi.org/10.22146/poetika.35611.

Sumiyadi, S. (2016). Revitalisasi Novel Burak Siluman Karya Mohamad Ambri Ke Dalam Cerpen "Burak Siluman" Karya Ajip Rosidi. Litera, 15(2). https://doi.org/10.21831/ltr.v15i2.11833.

Taryanti, T., \& Bahtiar, A. (2015). Feminisme Dalam Novel Geri Jora Karya Abidah El Khalieqy dan Implikasinya dalam Pembelajaran Sastra di Sekolah. DIALEKTIKA: Jurnal Bahasa, Sastra Dan Pendidikan Bahasa Dan Sastra Indonesia, 2(1). https://doi.org/10.15408/dialektika.v2i1.2202.

Utomo, R. O., Hasanah, M., \& Maryaeni, M. (2020). Telaah Nilai Toleransi Sosial Dalam Novel Karya Ahmad Tohari. Jurnal Pendidikan: Teori, Penelitian, Dan Pengembangan, 5(6), 792-802. https://doi.org/10.17977/jptpp.v5i6.13620. 